INTER NATIONAL MONETARY FUND

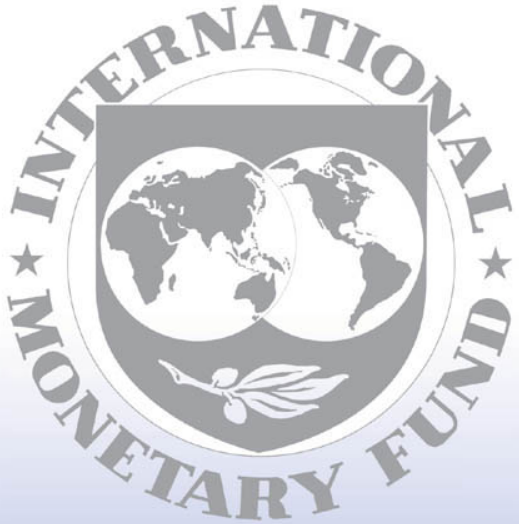

Staff

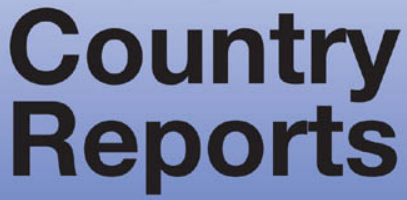




\section{Italy: Financial Sector Assessment Program- \\ Detailed Assessment of Observance of the IMF Code of Good Practices on Transparency in Monetary and Financial Policies-Banking Supervision}

This Detailed Assessment of Observance of the IMF Code of Good Practices on Transparency in Monetary and Financial Policies-Banking Supervision for Italy was prepared by a staff team of the International Monetary Fund as background documentation to the Financial Sector Assessment Program with the member country. It is based on the information available at the time it was completed in February 2006. The views expressed in this document are those of the staff team and do not necessarily reflect the views of the government of Italy or the Executive Board of the IMF.

The policy of publication of staff reports and other documents by the IMF allows for the deletion of market-sensitive information.

To assist the IMF in evaluating the publication policy, reader comments are invited and may be sent by e-mail to publicationpolicy@imf.org.

Copies of this report are available to the public from

International Monetary Fund $\bullet$ Publication Services

700 19th Street, N.W. • Washington, D.C. 20431

Telephone: (202) $6237430 \bullet$ Telefax: (202) 6237201

E-mail: publications@imf.org・Internet: http://www.imf.org

Price: $\$ 15.00$ a copy

International Monetary Fund

Washington, D.C. 
This page intentionally left blank

CInternational Monetary Fund. Not for Redistribution 


\section{FinANCIAL SeCtor AsSesSMent PROGRAm}

\section{DETAILED ASSESSMENT OF OBSERVANCE OF THE IMF CODE OF GOOD Practices ON TRANSPARENCY IN MONETARY AND Financial Policies-BANKING SuPERVISION}

\section{ITALY}

FEBRUARY 2006 
Contents

Transparency of Banking Supervision.........................................................................

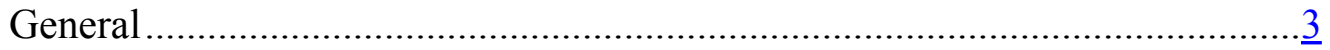

Institutional and market structure overview ……….......................................

Practice-by-practice assessment.......................................................................

Recommended action plan and authorities' response to the assessment ..........21

Tables

1. Practice-by-Practice Assessment of Observance of IMF's MFP Transparency

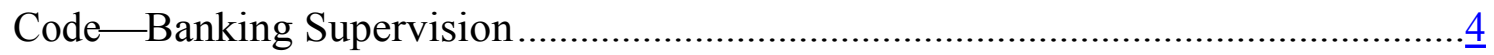

2. Recommended Action Plan to Improve Observance of IMF's MFP Transparency

Code Practices-Banking Supervision 


\section{TRANSPARENCY OF BANKING SUPERVISION}

\section{General}

1. This assessment examines the observance by the Banca d'Italia (BI) of the IMF's Code of Good Practices on Transparency in Monetary and Financial Policies (MFPT Code) for banking supervision. It was conducted as part of the IMF Financial Sector Assessment Program (FSAP). The assessment was based on a pre-mission work; a review of relevant laws, regulations, and policies; documentation provided on the BI Web site and in a variety of official BI publications; and on discussions with the BI and market participants. ${ }^{1}$ The assessment was based on the MFPT Code, and has taken into account the implementation issues mentioned in the Supporting Document to the MFPT Code.

2. The Italian authorities cooperated fully with the assessment and provided the necessary information and documentation requested by the mission.

\section{Institutional and market structure overview}

3. In the area of banking supervision, broad objectives are defined in the 1993 Banking Law, as the sound and prudent management of supervised institutions, as well as the overall stability, efficiency and competitiveness of the financial system. The institutional framework and the relationship between financial agencies are defined in the 1998 Consolidated Law. The BI has established a structured and comprehensive public information system for the timely dissemination of data and information on policy developments and regulatory changes. Internal governance arrangements, the publication of audited financial statements and statutory provisions governing conflict of interest and staff conduct provide assurances of integrity.

4. Transparency in the conduct of policy may be further consolidated however, by more specifically explaining the broad objectives of stability, efficiency and competitiveness and openly discussing any potential tradeoffs. A more extensive discussion of the progress achieved in achieving these objectives would also serve to complement accountability in BI practices such as the regular reporting on banking supervision activities, key public speeches by its senior officials and the Governor's testimony to Parliamentary committees. While formal procedures for cooperation and the exchange of information are in place, disclosing the practical modalities for cooperation and the type of information that is exchanged would enhance transparency in this policy area.

\footnotetext{
${ }^{1}$ The mission took place in July 2005; the assessment was carried out by Marie Thérèse Camilleri Gilson (IMF). Thus the assessment does not integrate changes as a function of the adoption of the Savings Law on December 28, 2005, except as noted in relevant footnotes.
} 


\section{Practice-by-practice assessment}

5. The assessment of observance with each practice of the MFPT Code is made qualitatively, based on existing laws, regulations, and practices. A five-part assessment system is used: observed, implying full observance or with insignificant shortcomings; broadly observed, where weaknesses might exist but these are not seen as being of a significant nature so as to raise serious doubts about the BI's ability to achieve the objective of that practice; partly observed, where shortcomings are sufficient to raise doubts about the BI's ability to achieve observance and could affect policy effectiveness; not observed, where the practice is not being observed and no substantive progress has been recorded toward achieving the objectives of the practice; and not applicable, where, due to the institutional and legal framework, the transparency practice is not relevant.

\section{Table 1. Practice-by-Practice Assessment of Observance of IMF's MFP Transparency Code-Banking Supervision}

\begin{tabular}{|c|c|}
\hline \multicolumn{2}{|c|}{ 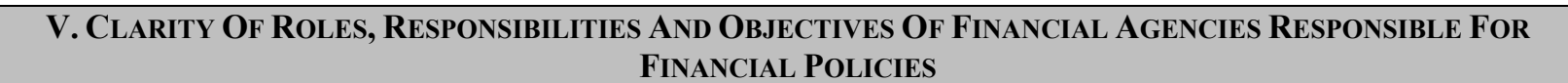 } \\
\hline 5.1 & $\begin{array}{l}\text { The broad objective(s) and institutional framework of financial agencies should be clearly } \\
\text { defined, preferably in relevant legislation or regulation. }\end{array}$ \\
\hline Description & $\begin{array}{l}\text { The broad objectives and the institutional framework of banking supervision are defined in } \\
\text { the } 1993 \text { Banking Law (legislative Decree } 385 \text { of September 1993); and, for the BI and Consob } \\
\text { (the Companies and Stock Exchange Commission, or Commissione nazionale per le società e la } \\
\text { borsa), the Consolidated law on Financial Intermediation (Legislative Decree 58, of } 24 \\
\text { February 1998). } \\
\text { The Banking Law contains the general rules governing banks and banking groups, identifies the } \\
\text { credit authorities - the Interministerial Committee for Credit and Savings (Comitato } \\
\text { interministeriale per il credito ed il risparmio, or ICCS), the Ministry of Economy and Finance as } \\
\text { chairman of the ICCS, and the BI-and specifies their related powers. According to the } 1993 \\
\text { Banking Law (Article 5), the objectives of the credit authorities in their exercise of supervisory } \\
\text { powers, are the sound and prudent management of the institutions subject to supervision, the } \\
\text { overall stability, efficiency and competitiveness of the financial system and compliance with the } \\
\text { provisions concerning credit. } \\
\text { The organization, the jurisdiction and the responsibilities of the BI are also regulated in the bylaws } \\
\text { of the BI (ratified by Royal Decree no. 1067/1936 as subsequently amended). Further to Articles } 2 \text {, } \\
3 \text { and } 4 \text { of the Banking Law, the BI is responsible for banking supervision and is entrusted with the } \\
\text { power of authorization and the functions of supervision based on prudential returns, inspection and } \\
\text { regulation. Within this framework the BI formulates and implements general resolutions of the } \\
\text { ICCS and measures within the scope of the authority of the Minister of Economy and Finance that } \\
\text { are specifically indicated in the Banking Law. The BI issues regulations and instructions as well as } \\
\text { specific measures regarding institutions subject to supervision. } \\
\text { The BI is also responsible for the prudential supervision of nonbank financial intermediaries, } \\
\text { Italian securities firms (società di intermediazione mobiliare, or SIMs) and asset management } \\
\text { companies (including investment funds and SICAV). Banks and other financial intermediaries, } \\
\text { eventually parts of banking groups, that provide investment services governed by the Consolidated } \\
\text { Law on Financial Intermediation are supervised not only by the BI but also by Consob for matters }\end{array}$ \\
\hline
\end{tabular}




\begin{tabular}{|c|c|}
\hline & $\begin{array}{l}\text { regarding transparency and proper conduct (Article 5). The Italian Foreign Exchange Office } \\
\text { (Ufficio Italiano dei Cambi, or UIC) is chaired by the BI Governor; it checks compliance with anti- } \\
\text { money-laundering legislation by intermediaries pursuant to Law 197/1991 and keeps the register of } \\
\text { minor nonbank financial intermediaries. } \\
\text { The Consolidated Law on Financial intermediation requires cooperation between Consob and the } \\
\text { BI in areas of shared jurisdiction, thereby minimizing costs incurred by supervised entities. It also } \\
\text { states that the supervisory authorities may not invoke professional secrecy in their mutual relations. }\end{array}$ \\
\hline Assessment & Observed \\
\hline Comments & \\
\hline 5.1 .1 & The broad objective(s) of financial agencies should be publicly disclosed and explained. \\
\hline Description & 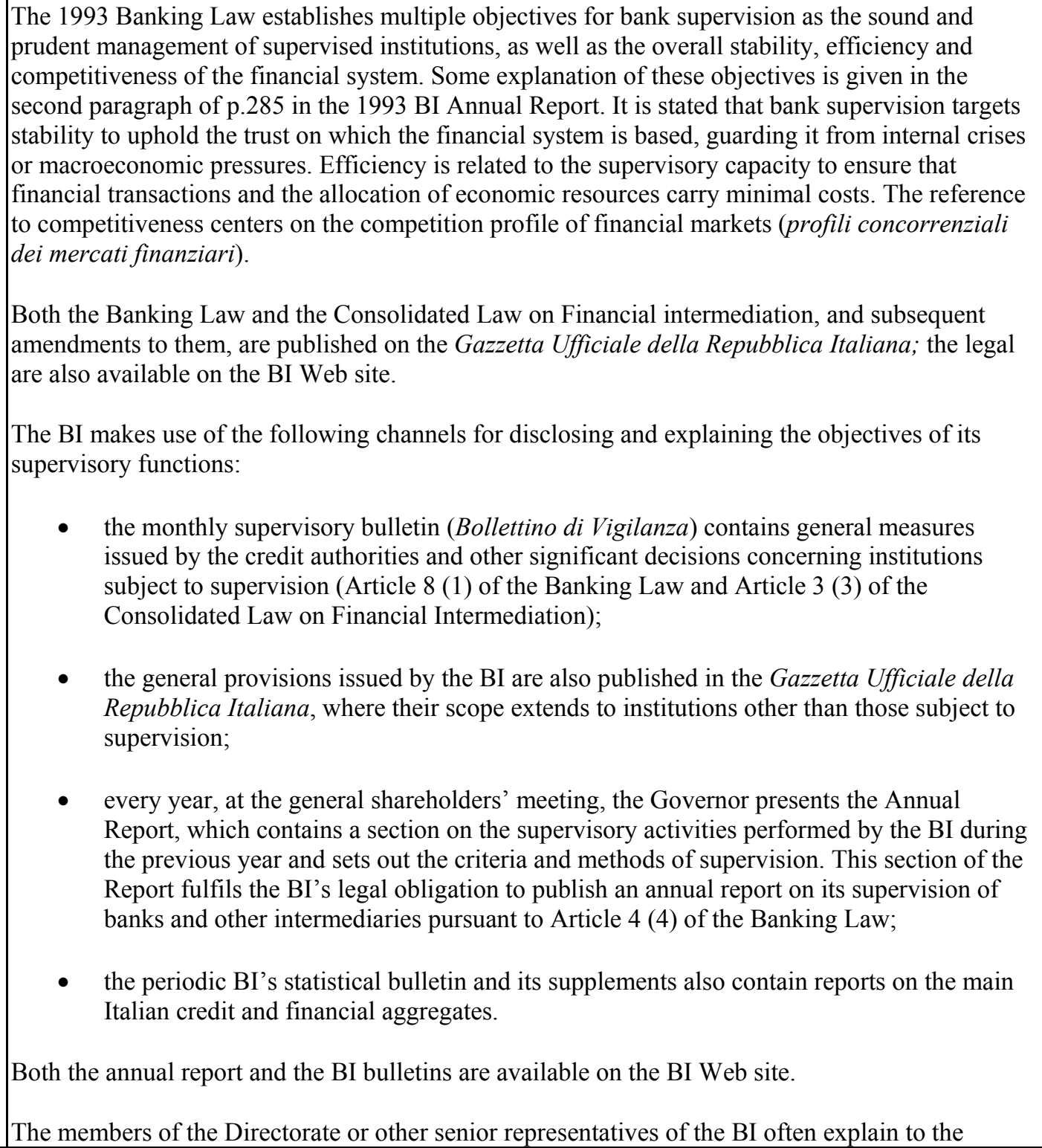 \\
\hline
\end{tabular}




\begin{tabular}{|c|c|}
\hline & $\begin{array}{l}\text { Parliament and to the public (through speeches and press releases) the criteria and results of } \\
\text { supervisory activities. }\end{array}$ \\
\hline Assessment & Broadly observed \\
\hline Comments & $\begin{array}{l}\text { The objectives established in the Banking Law could be further elaborated and disclosed in a } \\
\text { document that is more readily accessible to the public than the Annual Report archives. As the } \\
\text { analytical and operating framework for banking supervision by the BI may evolve, the emphasis it } \\
\text { places on these different objectives may change. In the presence of such multiple objectives, it is } \\
\text { important for each objective to be disclosed and explained in more depth on an ongoing basis. This } \\
\text { would enable the public to be aware of any relative priorities, any linkages and any potential } \\
\text { tradeoffs that may arise. }{ }^{2}\end{array}$ \\
\hline 5.1 .2 & $\begin{array}{l}\text { The responsibilities of the financial agencies and the authority to conduct financial policies should } \\
\text { be publicly disclosed. }\end{array}$ \\
\hline Description & $\begin{array}{l}\text { The responsibility of the BI for banking supervision is publicly disclosed (see 5.1.1). Its authority } \\
\text { to conduct financial policies stems from the legal basis described above (see 5.1). The BI is } \\
\text { entrusted with the power of authorization and the functions of supervision based on prudential } \\
\text { returns, inspection and regulatory powers. }\end{array}$ \\
\hline Assessment & Observed \\
\hline \multicolumn{2}{|l|}{ Comments } \\
\hline 5.1 .3 & $\begin{array}{l}\text { Where applicable, the broad modalities of accountability for financial agencies should be publicly } \\
\text { disclosed. }\end{array}$ \\
\hline Description & $\begin{array}{l}\text { Article } 4 \text { (3) of the Banking Law provides that the BI must establish and give prior public notice of } \\
\text { the principles and methods of its supervisory activity and must publish an annual report on its } \\
\text { supervisory activity. Accountability is also upheld through regular reporting to Parliament. (See } \\
\text { also 8.1). } \\
\text { The BI is subject to the general principles provided for all public administrations by Article } 97 \text { of } \\
\text { the Italian Constitution, regarding good functioning and impartiality, and by Law } 241 / 1990 \text { on } \\
\text { Transparency and the public rights of access to administrative documents. Article } 4 \text { (3) of the } \\
\text { Banking Law confirms that the provisions of this Law also apply to the BI (insofar as they are } \\
\text { compatible with its statutory functions) and allows the Governor of the BI to adopt general } \\
\text { administrative measures pursuant to such provisions. These include modalities of, and exceptions } \\
\text { to the public right of access to administrative documents held by the BI. (See also 6.1.1). }\end{array}$ \\
\hline Assessment & Observed \\
\hline \multicolumn{2}{|l|}{ Comments } \\
\hline 5.1 .4 & $\begin{array}{l}\text { Where applicable, the procedures for appointment, terms of office, and any general criteria for } \\
\text { removal of the heads and members of the governing bodies of financial agencies should be }\end{array}$ \\
\hline
\end{tabular}

\footnotetext{
${ }^{2}$ Subsequent to the assessment, the Savings Law of December 28, 2006 transferred the responsibility for regulating anti-competition behavior to the Anti-trust Authority, while BI and the Anti-trust Authority were given shared responsibility for banks' mergers and acquisitions.
} 
publicly disclosed.

The procedures for appointment, terms of office and the criteria for removal of the BI governing bodies are laid down in its Statute, originally adopted in form of Royal Decree (R.D. 11 June 1936, n. 1067) and subsequently modified by Presidential Decrees, all of which published in the Gazzetta Ufficiale della Repubblica Italiana; an updated version of the statute is available on the BI Web site.

According to Article 5 of the latter "the powers of the Bank are vested in: $a$ ) the General Meeting of Shareholders; $b$ ) the Board of Directors and the Committee of the Board of Directors [hereinafter the Board Committee]; $c$ ) the Directorate, composed of the Governor, the Director General and two Deputy Directors General." Only the Governor is entrusted with policy formulation and implementation in the area of banking supervision. The Board Committee has an advisory role, intervening on administrative matters upon a request by the Governor. Specific responsibilities may however be entrusted by the Governor to the other members of the Directorate (Articles 28 and 29). Oversight by auditors and examiners (Article 23) is limited to the control of administration with regard to statutory requirements.

The procedures for appointment are set out in the BI Statute:

- According to Article 17, thirteen members of the Board of Directors are elected by the General Meetings of Shareholders at the main branches of the Bank, with one director elected for each main branch. They serve for a term of five years and may be re-elected. A meeting of the Board of Directors may be called by the senior Director (in terms of appointment and age) to appoint and dismiss the Governor (Article 19).

- The Board also appoints four of the directors at its first meeting each year to form, together with the Governor, the Board Committee (Article 18).

- The Governor may call a Board Meeting to appoint and dismiss members of the Directorate.

- Article 19 of the BI Statute adds that "appointments and dismissals must be approved by a decree of the President of the Republic acting on a proposal from the President of the Council of Ministers in agreement with the Minister of the Treasury after consulting the Council of Ministers."

Qualification criteria for the head and members of the BI governing bodies are also established in the Statute.

- According to the general provisions of Article 59 and 60, the Governor, members of the Board and Directorate, may not hold political office, be members of any bank, engage in commerce, operate in the stock exchange, or hold positions of responsibility in any company, except where authorized by the Board, and then only in the recognized interests of the Bank.

The procedures for dismissing the Governor, the Director General and the two Deputy Directors General are set out in the BI Statute (Article 19) which entrusts the Board of Directors with this responsibility, subject to a resolution from two thirds of its members (under the chairmanship of the senior Director for the dismissal of the Governor).

There is a lack of clarity as to the duration of the Governor's mandate and the criteria for his dismissal.

- The BI Statute gives the Governor of the BI a mandate for an unlimited period of time, although Article 14 of the ESCB Statute (Protocol on the Statute of the European System of Central Banks and of the European Central Bank) requires that "each Member State shall ensure [...] that its national legislation, including the statutes of its national central bank, is compatible with this Treaty and this Statute." It stipulates that "the statutes of the 


\begin{tabular}{|c|c|}
\hline & $\begin{array}{l}\text { national central banks shall, in particular, provide that the term of office of a Governor of } \\
\text { a national central bank shall be no less than five years." The assessment of compliance } \\
\text { with the BCP noted that the ECB has taken the view that insofar as "indefinite" is } \\
\text { interpreted as being "in excess of five years," the Statute of the BI is in line with the } \\
\text { requirements of national legislation set out in that of the ESCB. } \\
\text { - In addition, the BI Statute does not specify any criteria for removal of the Governor and } \\
\text { members of the governing bodies. Article } 14 \text { of the ESCB Statute also stipulates that } \\
\text { national legislation should provide that "a Governor may be relieved from office only if } \\
\text { he no longer fulfils the conditions required for the performance of his duties or if he has } \\
\text { been guilty of serious misconduct." } \\
\text { - In the } 1998 \text { EMI Convergence Report, there is however a reference to the direct } \\
\text { applicability of the Treaty insofar as the criteria for dismissing the Governor are } \\
\text { concerned suggesting that Article } 14.2 \text { of the ECB Treaty applies in the absence of } \\
\text { specific provisions in the national legislation. } \\
\text { There are no provisions in the BI Statute that relate to the criteria for dismissing the other members } \\
\text { of the Directorate, namely the Director General and the two Deputy Directors General. The BI } \\
\text { stated that safeguards against arbitrary dismissal are set out in case law. This establishes that } \\
\text { members of governing bodies may only be removed on the grounds of nonfulfillment of the goals } \\
\text { of such bodies. It can be inferred from the discussion of general principles contained in the } 1998 \\
\text { EMI Convergence Report that provisions relating to the Governor's dismissal may be extended to } \\
\text { other members of the governing bodies. }\end{array}$ \\
\hline Assessment & Broadly observed \\
\hline Comments & $\begin{array}{l}\text { A publicly disclosed reference which would clearly explain (i) the ECB opinion of the conformity } \\
\text { of the BI Statute with the requirements of Article } 14.2 \text { of the ESCB Statute, insofar as the } \\
\text { Governor is concerned, and (ii) the general criteria for removal of the heads and members of the } \\
\text { governing bodies would be required for this practice to be fully observed. Further to this } \\
\text { recommendation, BI has amended the on-line pamphlet entitled "le persone e l'organizzazione." } \\
\text { The recently adopted Savings Law now explicitly mentions Article } 14.2 \text { of the ESCB Statutes for } \\
\text { the Governor's dismissal procedures. }\end{array}$ \\
\hline 5.2 & The relationship between financial agencies should be publicly disclosed. \\
\hline Description & $\begin{array}{l}\text { As explained under 5.1, the relationship between the BI and Consob is defined in the Consolidated } \\
\text { Law on Financial Intermediation, and publicly disclosed through the Gazzetta Ufficiale della } \\
\text { Repubblica Italiana and the Web sites of the two authorities. } \\
\text { Cooperation between the BI and other authorities for the purposes related to the supervision of } \\
\text { banks is also regulated by the Banking Law. } \\
\text { - According to Article } 7 \text { of the Banking Law, the BI, the Consob, the pension fund } \\
\text { supervisory authority (Commissione di vigilanza sui fondi pensioni), the insurance } \\
\text { supervisor (ISVAP) and the Italian foreign exchange office (Ufficio Italiano Cambi) shall } \\
\text { cooperate by exchanging information for the purpose of facilitating their respective } \\
\text { functions. These authorities may not invoke professional secrecy in their mutual relations. } \\
\text { Moreover, according to Article } 7 \text { (8) and (9)of the Banking Law, the BI may exchange } \\
\text { information with the following entities: a) administrative and judicial authorities in } \\
\text { connection with liquidation or insolvency proceedings in Italy or abroad involving } \\
\text { authorized persons; b) bodies responsible for the administration of compensation systems. }\end{array}$ \\
\hline Assessment & Observed \\
\hline
\end{tabular}




\begin{tabular}{|c|c|}
\hline Comments & \\
\hline 5.3 & The role of oversight agencies with regard to payment systems should be publicly disclosed. \\
\hline Description & Not relevant for banking supervision. \\
\hline Assessment & Not applicable \\
\hline \multicolumn{2}{|l|}{ Comments } \\
\hline 5.3 .1 & $\begin{array}{l}\text { The agencies overseeing the payment system should promote the timely public disclosure of } \\
\text { general policy principles (including risk management policies) that affect the robustness of } \\
\text { systemically important payment systems. }\end{array}$ \\
\hline Description & Not relevant for banking supervision . \\
\hline Assessment & Not applicable \\
\hline \multicolumn{2}{|l|}{ Comments } \\
\hline 5.4 & $\begin{array}{l}\text { Where financial agencies have oversight responsibilities for self-regulatory organizations } \\
\text { (e.g., payment systems), the relationship between them should be publicly disclosed. }\end{array}$ \\
\hline Description & $\begin{array}{l}\text { The BI does not have oversight responsibilities for self-regulatory organizations engaged in } \\
\text { banking supervision. }\end{array}$ \\
\hline Assessment & Not applicable \\
\hline \multicolumn{2}{|l|}{ Comments } \\
\hline 5.5 & $\begin{array}{l}\text { Where self-regulatory organizations are authorized to perform part of the regulatory and } \\
\text { supervisory process, they should be guided by the same good transparency practices specified } \\
\text { for financial agencies. }\end{array}$ \\
\hline Description & $\begin{array}{l}\text { No self-regulatory organizations are authorized to perform part of the regulatory and supervisory } \\
\text { process. }\end{array}$ \\
\hline Assessment & Not applicable \\
\hline \multicolumn{2}{|l|}{ Comments } \\
\hline \multicolumn{2}{|r|}{ VI. OPEN PROCESS FOR FORMULATING AND REPORTING OF FINANCIAL POLICIES } \\
\hline 6.1 & $\begin{array}{l}\text { The conduct of policies by financial agencies should be transparent, compatible with } \\
\text { confidentiality considerations and the need to preserve the effectiveness of actions by } \\
\text { regulatory and oversight agencies. }\end{array}$ \\
\hline Description & $\begin{array}{l}\text { Transparency in the conduct of bank supervision policies of the BI is legally mandated: } \\
\text { - Article } 4 \text { (2) of the Banking Law stipulates that the BI must gives prior public notice of } \\
\text { the principles and methods of the supervisory activity it establishes. It is also required to } \\
\text { publish an annual report on its supervisory activity. The annual report includes an } \\
\text { extensive chapter on developments in the regulation and structure of the Italian banking } \\
\text { and financial system, the risks, profitability and capital adequacy of intermediaries, and } \\
\text { inspections carried out in the course of supervisory activity. } \\
\text { - According to Article } 8 \text { (1) of the Consolidated Law on banking (see 5.1.1), the BI is }\end{array}$ \\
\hline
\end{tabular}




\begin{tabular}{|c|c|}
\hline & $\begin{array}{l}\text { required to publish a monthly supervisory bulletin containing the general measures } \\
\text { adopted by the credit authorities and other significant decisions related to supervision. } \\
\text { These are published within two months of being adopted. The bulletin is available on the } \\
\text { BI Web site. } \\
\text { - As mentioned above, the BI is also subject to the general principles provided for all public } \\
\text { administrations by Article } 97 \text { of the Italian Constitution, regarding good functioning and } \\
\text { impartiality, and by Law } 241 / 1990 \text { on Transparency and the public rights of access to } \\
\text { administrative documents. } \\
\text { The BI also publishes reports on questions within the scope of its authority, in conjunction with } \\
\text { parliamentary hearings and other occasions. } \\
\text { The extent of disclosure of the procedures for information sharing and consultation between the BI } \\
\text { and other financial agencies, is limited to a provision on the legal requirement to cooperate, } \\
\text { together with a broad definition of the objectives of such cooperation. Cooperation and the } \\
\text { exchange of information between the BI and its counterparts across the EU is more readily } \\
\text { disclosed in the Annual Report on BI activities in field of banking supervision. }\end{array}$ \\
\hline Assessment & Broadly observed \\
\hline Comments & $\begin{array}{l}\text { There is little public disclosure of the details on protocols that define the practical modalities of } \\
\text { cooperation between domestic financial agencies, and the actual procedures they follow for } \\
\text { information sharing apart from the notification of a new MOU in the Annual Report. (See also } \\
6.1 .5 \text { ) }\end{array}$ \\
\hline 6.1 .1 & $\begin{array}{l}\text { The regulatory framework and operating procedures governing the conduct of financial policies } \\
\text { should be publicly disclosed and explained. }\end{array}$ \\
\hline Description & $\begin{array}{l}\text { The BI publishes a collection of the relevant legal sources in banking supervision (laws, relevant } \\
\text { implementing measures adopted by the ICCS, BI, and by the Minister of Economy, relevant } \\
\text { communications to the system), and posts them on its Web site. } \\
\text { The BI's conduct must comply, among others, with the principles on disclosure laid down in } \\
\text { Article } 4 \text { of the Banking Law, as referred to above. In particular, Article } 4 \text { (3) of the Banking Law } \\
\text { requires the BI in the exercise of its banking supervision functions to indicate reasons for the } \\
\text { decisions it takes and to publish measures for general application. Provisions of the Transparency } \\
\text { Law } 241 / 1990 \text { (see 5.1.3) also apply to the BI by virtue of the same Article. The BI has issued } \\
\text { special rules of procedure to regulate its functioning (Internal Regulation no.177 of 1993), as well } \\
\text { as two sets of regulations (dated } 16 \text { May } 1994 \text { ) that set out the modalities for public access to } \\
\text { administrative documentation held by the BI and limitations thereof. (See 5.1.3). Transparency of } \\
\text { administrative procedures in the BI is also discussed in the introduction to the April 1999 } \\
\text { supervisory instructions (section 3, page 3). The texts of the supervisory instructions for banks are } \\
\text { included in volumes which are printed and distributed to the supervised entities; interested parties } \\
\text { may also obtain printed copies of such texts from the BI. The instructions are also available on the } \\
\text { BI Web site. The preamble to supervisory instructions always refers to the legal basis for the BI } \\
\text { authority and explains the general principles and objectives of the relevant measures. }\end{array}$ \\
\hline Assessment & Observed \\
\hline \multicolumn{2}{|l|}{ Comments } \\
\hline 6.1 .2 & $\begin{array}{l}\text { he regulations for financial reporting by financial institutions to financial agencies should be } \\
\text { ublicly disclosed. }\end{array}$ \\
\hline
\end{tabular}




\begin{tabular}{|c|c|}
\hline Description & $\begin{array}{l}\text { The legal basis for financial institutions' reporting to the BI is established in the Banking Law. } \\
\text { - Article } 51 \text { requires banks to send periodic reports and financial statements in the manner } \\
\text { and within the time limits established by the BI. } \\
\text { - Further to Article } 61 \text {, the BI is responsible for supervision on a consolidated basis. The } \\
\text { Bank thereby requires the holding company (parent bank or financial company with } \\
\text { registered office in Italy) to transmit consolidated reports and data (including data on a } \\
\text { sub-consolidated basis relating to specific sectors of activity of the banking group) } \\
\text { concerning the banks, financial companies and instrumental companies belonging to the } \\
\text { group and the companies in which the group has an equity interest of at least } 20 \text { per cent. } \\
\text { The procedures for completing statistical reports and consolidating accounts are established by the } \\
\text { BI and communicated to supervised institutions through manuals, published and posted on the BI } \\
\text { Web site. These manuals set out the data which must be reported and the methods for calculating } \\
\text { each aggregate. The methods and procedures for gathering financial reports from the supervised } \\
\text { intermediaries are also disclosed on the BI Web site. }\end{array}$ \\
\hline Assessment & Observed \\
\hline Comments & \\
\hline 6.1 .3 & $\begin{array}{l}\text { The regulations for the operation of organized financial markets (including those for issuers of } \\
\text { traded financial instruments) should be publicly disclosed. }\end{array}$ \\
\hline Description & Not relevant for banking supervision \\
\hline Assessment & Not applicable \\
\hline Comments & \\
\hline 6.1 .4 & $\begin{array}{l}\text { Where financial agencies charge fees to financial institutions, the structure of such fees should be } \\
\text { publicly disclosed. }\end{array}$ \\
\hline Description & The BI does not charge any fees for banking supervision. \\
\hline Assessment & Not applicable \\
\hline Comments & \\
\hline 6.1 .5 & $\begin{array}{l}\text { Where applicable, formal procedures for information sharing and consultation between financial } \\
\text { agencies (including central banks), domestic and international should be publicly disclosed. }\end{array}$ \\
\hline Description & $\begin{array}{l}\text { According to the Consolidated Law on Financial Intermediation and the Banking Law, the BI } \\
\text { cooperates with other domestic and foreign supervisory authorities both through ongoing formal } \\
\text { and informal contacts and coordinated action and by exchanging information. } \\
\text { In particular, as already mentioned under 5.1, the Consolidated Law on Financial Intermediation } \\
\text { emphasizes the need for effective cooperation between the BI and Consob. It requires them to } \\
\text { coordinate policies so that the costs incurred by supervised intermediaries would be minimized. } \\
\text { The law also states that the supervisory authorities may not invoke professional secrecy in their } \\
\text { mutual relations. Pursuant to Article } 10 \text {, the BI and Consob, in exercising their respective power of } \\
\text { inspection on intermediaries that provide investment and collective asset management services, } \\
\text { must notify each other of the inspections they undertake. Each authority may request the other to } \\
\text { carry out on-site visits to obtain required information. } \\
\text { Special protocols have been signed with Consob and Isvap for mutual cooperation in periodic high- }\end{array}$ \\
\hline
\end{tabular}




\begin{tabular}{|c|c|}
\hline & $\begin{array}{l}\text { level meetings on matters of common interest. An understanding has also been reached with the } \\
\text { UIC on the supervision of banks for the purposes of combating money-laundering. } \\
\text { The BI cooperates and exchanges information with the authorities of the EU, those of its member } \\
\text { states and counterparts in other countries. Any information thereby received may not be } \\
\text { transmitted to other Italian authorities or to third parties without the consent of the authority that } \\
\text { provided it. In particular, the BI may cooperate with supervisory authorities of other EU member } \\
\text { states to carry out supervision on a consolidated basis in the case of banking groups operating in } \\
\text { more than one country. } \\
\text { Information sharing agreements are contained in bilateral memoranda of understanding which are } \\
\text { not publicly disclosed. However, the BI's Annual Report comments on the party to the agreement } \\
\text { and the date of their conclusion. }\end{array}$ \\
\hline Assessment & Partly observed \\
\hline Comments & $\begin{array}{l}\text { While cooperation and the exchange of information between the BI and its counterparts across the } \\
\text { EU is readily disclosed in the BI Annual Report, the extent of disclosure of the procedures for } \\
\text { information sharing and consultation between the BI and other financial agencies, is limited to a } \\
\text { provision on the legal requirement to cooperate, together with a broad definition of the objectives } \\
\text { of such cooperation. The disclosure policy could be broadened to include information on practical } \\
\text { modalities, beyond public notification of the date of, and the parties to, an MOU signature. In } \\
\text { particular, the MOUs between the BI and other domestic financial agencies should be disclosed for } \\
\text { this practice to be fully observed. Subsequent to this assessment, the MOU governing the } \\
\text { cooperation and exchange of information between BI and Consob was made public on the Web site } \\
\text { of the two institutions. }\end{array}$ \\
\hline 6.2 & $\begin{array}{l}\text { Significant changes in financial policies should be publicly announced and explained in a } \\
\text { timely manner. }\end{array}$ \\
\hline Description & $\begin{array}{l}\text { According to Article } 8 \text { (1) of the Banking Law, the BI publishes a monthly supervisory bulletin } \\
\text { containing the general measures adopted by the credit authorities and other significant decisions } \\
\text { (see } 5.1 .1 \text { and } 6.1 \text { ). These are published within two months of being adopted and are posted on the } \\
\text { BI Web site. General provisions issued by the BI are also published in the Gazzetta Ufficiale della } \\
\text { Repubblica Italiana where their scope extends beyond supervised entities. Although publication in } \\
\text { the official gazette is only mandatory where the scope of the measures extends to institutions other } \\
\text { than those subject to supervision, the BI also publishes other general provisions. } \\
\text { When the BI issues or changes regulations, this is announced and explained through press releases } \\
\text { and direct communication with affected intermediaries via the BI branches. There is a presumption } \\
\text { for consultation (see } 6.4 \text { below). The BI also communicates with the financial system through } \\
\text { interpretative recommendations, guidance or instructions for the application of regulations within } \\
\text { its jurisdiction. Clarifications on technical issues are also provided by senior officials participating } \\
\text { in seminars, conferences, and industry meeting. In addition, detailed information on developments } \\
\text { in the regulation and the structure of the Italian banking and financial system is provided in the } \\
\text { relevant chapter of the Annual Report. }\end{array}$ \\
\hline Assessment & Observed \\
\hline \multicolumn{2}{|l|}{ Comments } \\
\hline 6.3 & $\begin{array}{l}\text { cies should issue periodic public reports on how their overall policy objectives } \\
\text { ued. }\end{array}$ \\
\hline
\end{tabular}




\begin{tabular}{|c|c|}
\hline Description & $\begin{array}{l}\text { The Annual Report is the means by which the BI discloses information on supervisory activities, } \\
\text { explaining inter alia the modalities through which policy objectives are being pursued. } \\
\text { The monthly supervisory bulletin also provides a discussion and explanation of new developments } \\
\text { in the international framework for banking supervision and the implications for the future activities } \\
\text { of the BI (see for example, p. } 13 \text { of the March } 2005 \text { bulletin relating to the revised framework for } \\
\text { international convergence of capital measurement and capital standards.) Other examples of how } \\
\text { the BI pursues its objectives in the area of banking supervision may be drawn from: (i) public } \\
\text { speeches by members of the Directorate (such as that of the Deputy Director General on Basel } 2 \\
\text { and IAS delivered at the November } 2004 \text { ABI Convention, or the Governor's address on economic } \\
\text { and banking perspectives at the July } 2004 \text { ABI Ordinary Assembly); and (ii) parliamentary } \\
\text { testimony (such as the testimony of the director of banking supervision to the financial committee } \\
\text { in connection with an inquiry into the diffusion of derivative financial instruments in } \\
\text { December 2004). }\end{array}$ \\
\hline Assessment & Observed \\
\hline \multicolumn{2}{|l|}{ Comments } \\
\hline 6.4 & $\begin{array}{l}\text { For proposed substantive technical changes to the structure of financial regulations, there } \\
\text { should be a presumption in favor of public consultations, within an appropriate period. }\end{array}$ \\
\hline Description & $\begin{array}{l}\text { Although there is no legal obligation to undertake public consultations, it is a common practice of } \\
\text { the BI, in relation to major changes of regulations within its jurisdiction, to consult the market. } \\
\text { This is normally done through the relevant associations representing interested parties, but also, if } \\
\text { necessary, with the assistance of external experts (such as university professors). Such } \\
\text { consultations may consist in an open period for submission of written comments or in meetings } \\
\text { with the most interested parties. Although the timeframe for such consultations is not specified, the } \\
\text { advance publication of information on proposed changes and the procedures for receiving } \\
\text { comments from market participants suggest that it is appropriate. } \\
\text { Examples of two-way communication may be drawn from (i) the consultation on credit derivatives } \\
\text { conducted by the BI with banks active in this segment of the market through the ABI between } \\
\text { December } 2004 \text { and March } 2005 \text {, the results of which are currently being considered by the BI } \\
\text { Governor; (ii) the public disclosure of a consultation paper on the national exercise of discretion } \\
\text { for Basel } 2 \text {. The BI also engages in EU-wide consultative procedures, with regard, for instance to } \\
\text { the proposal for the new capital requirements directive (see CEBS consultation paper on } \\
\text { supervisory disclosure of March 23, 2005). }\end{array}$ \\
\hline Assessment & Observed \\
\hline \multicolumn{2}{|l|}{ Comments } \\
\hline \multicolumn{2}{|r|}{ VII. PubliC AVAILABILITy Of Information On FinanCIAL POLICIES } \\
\hline 7.1 & $\begin{array}{l}\text { Financial agencies should issue a periodic public report on the major developments of the } \\
\text { sector(s) of the financial system for which they carry designated responsibility. }\end{array}$ \\
\hline Description & $\begin{array}{l}\text { The main periodic reports issued by the BI to report on developments are the monthly supervisory } \\
\text { bulletin and the Annual Report (see 5.1.1). While the bulletin contains information on measures } \\
\text { issued by the credit authorities and other significant decisions, the Annual Report contains a review } \\
\text { of supervisory activity performed by the BI during the previous year. These are supplemented by } \\
\text { periodic statistical bulletins reporting on the main Italian credit and financial aggregates. All the } \\
\text { reports are available on the BI Web site. }\end{array}$ \\
\hline Assessment & Observed \\
\hline
\end{tabular}




\begin{tabular}{|c|c|}
\hline Comments & \\
\hline 7.2 & $\begin{array}{l}\text { Financial agencies should seek to ensure that, consistent with confidentiality requirements, } \\
\text { there is public reporting of aggregate data related to their jurisdictional responsibilities on a } \\
\text { timely and regular basis. }\end{array}$ \\
\hline Description & 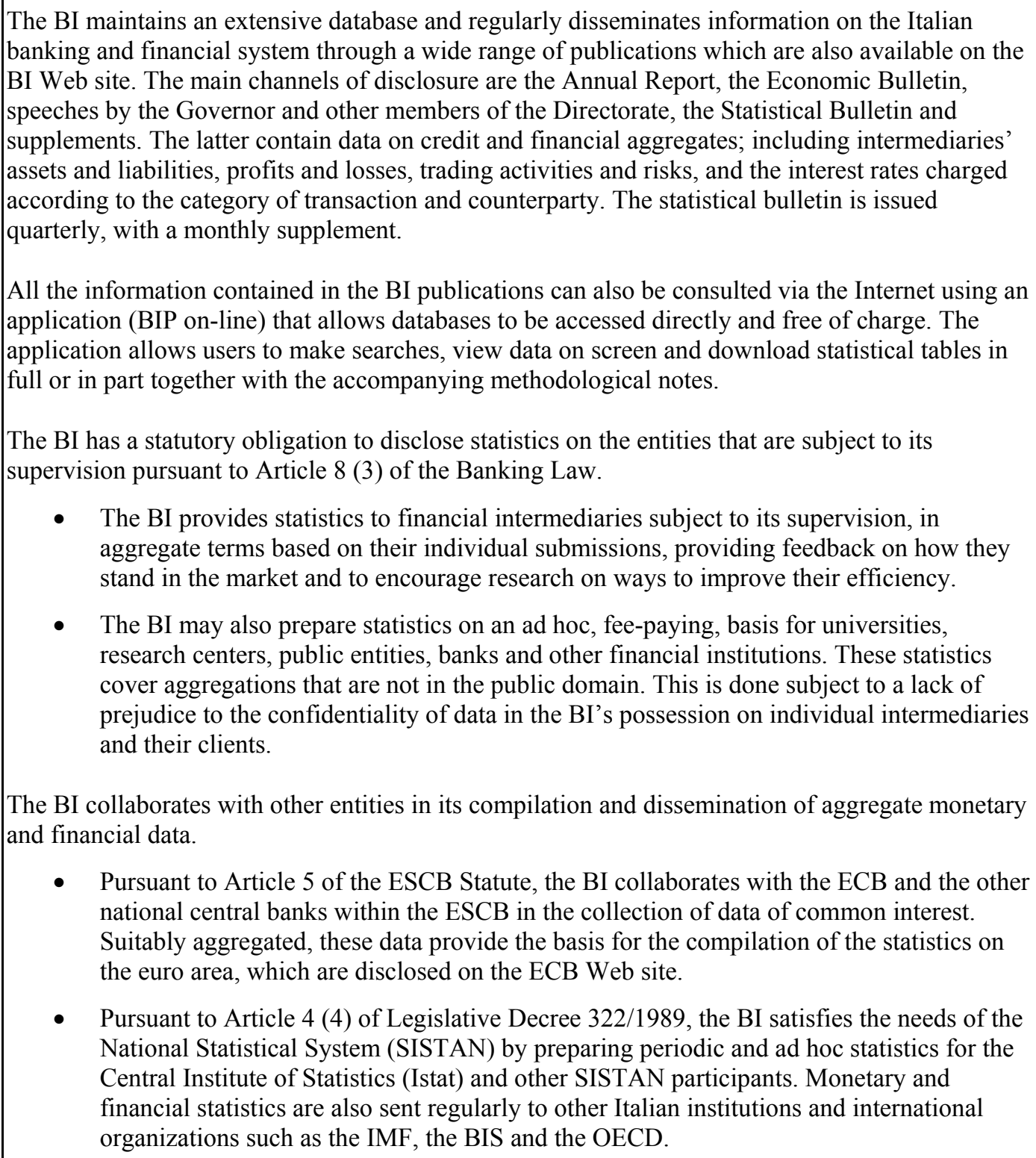 \\
\hline Assessment & Observed \\
\hline \multicolumn{2}{|l|}{ Comments } \\
\hline 7.3 & $\begin{array}{l}\text { Where applicable, financial agencies should publicly disclose their balance sheets on a pre- } \\
\text { announced schedule and, after a predetermined interval, publicly disclose information on } \\
\text { aggregate market transactions. }\end{array}$ \\
\hline
\end{tabular}




\begin{tabular}{|c|c|}
\hline Description & $\begin{array}{l}\text { The BI does not prepare disaggregated financial accounts for any function it performs, nor does it } \\
\text { engage in aggregate market transactions in the context of banking supervision. The balance sheet } \\
\text { published in the Annual Report also contains an income statement, the notes to the accounts, } \\
\text { including information on subsidiary and associated companies, the report of the board of auditors } \\
\text { and the report of the external auditors. The annual accounts are approved by the Ordinary General } \\
\text { Meeting of Shareholders, held in Rome not later than } 31 \text { May of each year (Article } 6 \text { of the } \\
\text { Statute). The Annual Report is also available in the BI's official Web site. Furthermore, the BI } \\
\text { sends to the Ministry of Economy and Finance a monthly financial statement drawn up according } \\
\text { to a template endorsed by the Ministry. These are also published on a monthly basis in the BI } \\
\text { Statistical Bulletin. }\end{array}$ \\
\hline Assessment & Observed \\
\hline \multicolumn{2}{|l|}{ Comments } \\
\hline 7.3 .1 & $\begin{array}{l}\text { Consistent with confidentiality and privacy of information on individual firms, aggregate } \\
\text { information on emergency financial support by financial agencies should be publicly disclosed } \\
\text { through an appropriate statement when such disclosure will not be disruptive to financial stability. }\end{array}$ \\
\hline Description & $\begin{array}{l}\text { Although financial institutions may request emergency liquidity assistance (ELA) from the BI, } \\
\text { they have not availed themselves of this option since the establishment of a new institutional } \\
\text { framework in 1999, pursuant to the establishment of the ESCB. The BI has full discretion as to } \\
\text { applicable interest rate and eligible collateral within the general framework of the ECB prohibition } \\
\text { on providing support for the purpose of state aid (i.e. below market rates). The most recent } \\
\text { instances of ELA provision date back to the early 1990s, when a full account of events was } \\
\text { disclosed through the BI Annual Report, together with information on the operations' terms and } \\
\text { amount. Should the BI act as lender of last resort in future liquidity crises, the presumption is } \\
\text { toward aggregate disclosure on an ex-post basis. }\end{array}$ \\
\hline Assessment & Observed \\
\hline \multicolumn{2}{|l|}{ Comments } \\
\hline 7.4 & Financial agencies should establish and maintain public information services. \\
\hline Description & $\begin{array}{l}\text { The BI has a structured public information system to disseminate information on its banking } \\
\text { supervision rules, statistics and data, economic bulletins and papers, legal publications, the Annual } \\
\text { Report on its activities, regional economic reports, speeches of senior officials and the texts of key } \\
\text { testimony given to Parliamentary committees. Press releases are prepared by the Communication } \\
\text { and Press Relations Division. All information material is published on the Web site. The relevant } \\
\text { texts are distributed to both public and private institutions, and the media. The Communication and } \\
\text { Press Relation Division of the Governor's Secretariat is in daily contact with all media } \\
\text { representatives to assist them in the interpretation of institutional communications. Press } \\
\text { conferences are organized at the end of international meetings. }\end{array}$ \\
\hline Assessment & Observed \\
\hline \multicolumn{2}{|l|}{ Comments } \\
\hline 7.4 .1 & $\begin{array}{l}\text { Financial agencies should have a publications program, including a periodic public report on their } \\
\text { principal activities issued at least annually. }\end{array}$ \\
\hline Description & $\begin{array}{l}\text { The publications program of the BI includes the supervisory bulletin, ongoing research and } \\
\text { statistical publications, speeches of officials, nontechnical descriptions of the role and functions of } \\
\text { the BI and information about the activities of the ESCB. The BI is required to publish its Annual }\end{array}$ \\
\hline
\end{tabular}




\begin{tabular}{|c|c|}
\hline & $\begin{array}{l}\text { Report by law. It also contains information on its banking supervisory activity. This is issued five } \\
\text { months after the end of the relevant reporting period. Access to these publications is free of charge. } \\
\text { (See 5.1.1,6.1,6,1.1 and 7.4). }\end{array}$ \\
\hline Assessment & Observed \\
\hline \multicolumn{2}{|l|}{ Comments } \\
\hline 7.4 .2 & $\begin{array}{l}\text { Senior financial agency officials should be ready to explain their institution's objective(s) and } \\
\text { performance to the public, and have a presumption in favor of releasing the text of their statements } \\
\text { to the public. }\end{array}$ \\
\hline Description & $\begin{array}{l}\text { BI senior officials regularly explain their institution's objectives and performance to the public by } \\
\text { delivering speeches at public meetings and media interviews. There is a presumption in favor of } \\
\text { releasing the text of their statements to the public, whether through the official bulletin, through the } \\
\text { media, or on the Web site. The BI publicly reports on questions within the scope of its authority in } \\
\text { parliamentary hearings, whenever the Parliament needs technical advice on subjects related to the } \\
\text { functions of the BI and on other occasions. Testimonies before Parliament are generally held by the } \\
\text { Governor, the Director General and the Deputies of the Director General, and, occasionally, by } \\
\text { other senior officials. Such testimonies before Parliament are also disclosed to the public by the } \\
\text { Parliament itself, in printed form and through its Web site. (See also 6.3). }\end{array}$ \\
\hline Assessment & Observed \\
\hline \multicolumn{2}{|l|}{ Comments } \\
\hline 7.5 & $\begin{array}{l}\text { Texts of regulations and any other generally applicable directives and guidelines issued by } \\
\text { financial agencies should be readily available to the public. }\end{array}$ \\
\hline Description & $\begin{array}{l}\text { In addition to the description of practices } 5.1 .1 \text { and } 6.1 .1 \text {, it must be noted that the text of any or } \\
\text { general measures is posted on the BI Web site upon adoption, in addition to publication in the } \\
\text { Gazzetta Ufficiale della Repubblica Italiana. The BI also issues a compendium containing all the } \\
\text { relevant regulations, which is also available on its Web site. }\end{array}$ \\
\hline Assessment & Observed \\
\hline \multicolumn{2}{|l|}{ Comments } \\
\hline 7.6 & $\begin{array}{l}\text { Where there are deposit insurance guarantees, policy-holder guarantees, and any other client } \\
\text { asset protection schemes, information on the nature and form of such protections, on the } \\
\text { operating procedures, on how the guarantee is financed, and on the performance of the } \\
\text { arrangement, should be publicly disclosed. }\end{array}$ \\
\hline Description & $\begin{array}{l}\text { The legal basis for the Italian deposit insurance schemes lies within the Banking Law (particularly } \\
\text { Article 96). The Banking Law governs membership, nature of the insurance systems, operating } \\
\text { procedures and powers of the BI. Two insurance schemes are operative in Italy: the Interbank } \\
\text { Deposit Guarantee Fund (Fondo Interbancario di Tutela dei Depositi - FITD), covering banks } \\
\text { incorporated as joint stock companies and cooperative banks; the Mutual Bank Depositors } \\
\text { Guarantee Fund (Fondo di Garanzia dei Depositanti del Credito Cooperativo), for mutual banks. } \\
\text { These are private-law consortia among banks and are administered by representatives of the } \\
\text { member banks. Originally created on a voluntary basis, they became compulsory with the } \\
\text { transposition of Community Directive 94/19/EC. } \\
\text { Membership is compulsory for Italian branches of non-EU banks as well, unless the } \\
\text { foreign scheme they participate in afford equivalent protection. The Italian branches of }\end{array}$ \\
\hline
\end{tabular}




\begin{tabular}{|c|c|}
\hline & 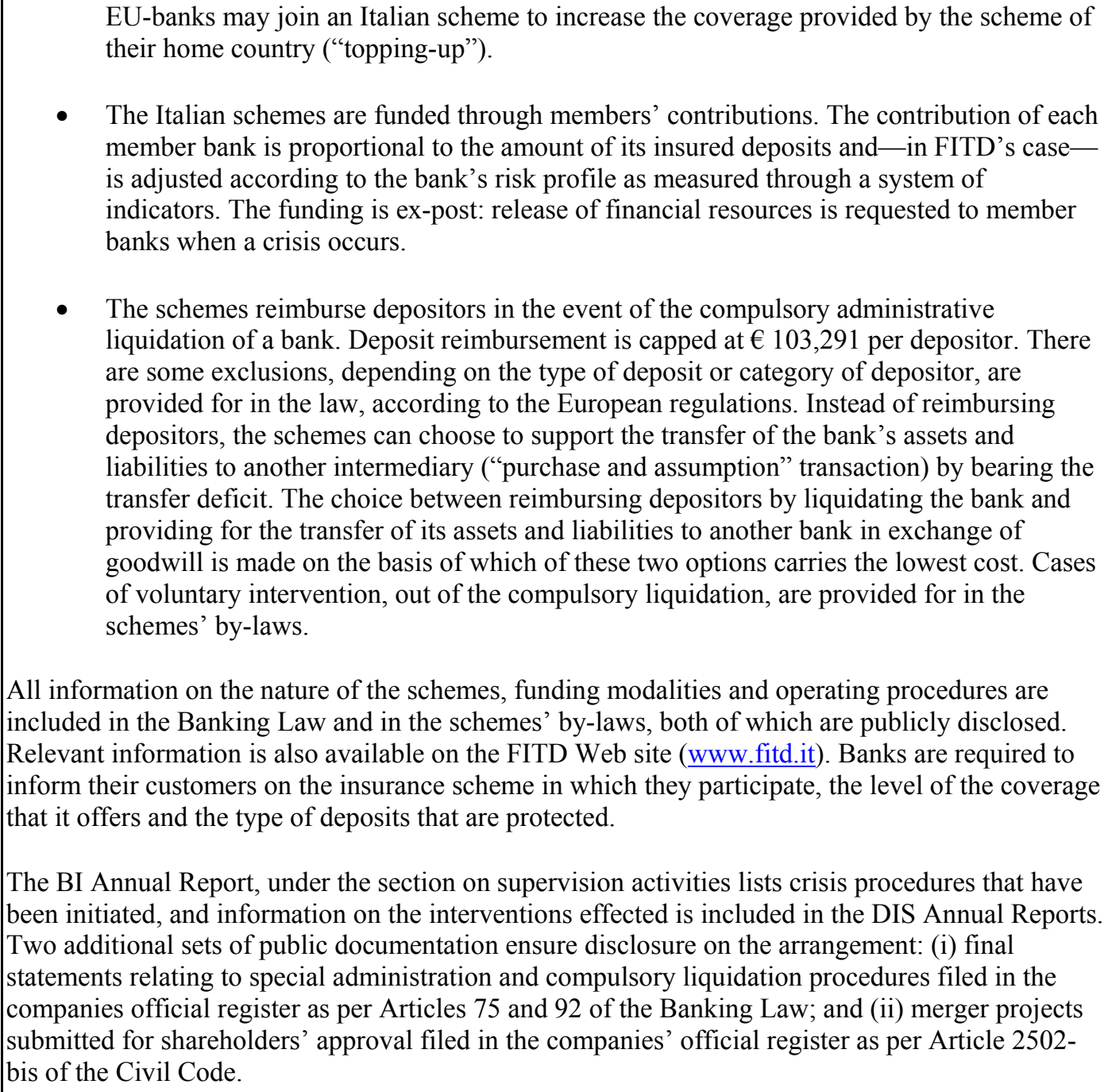 \\
\hline Assessment & Observed \\
\hline \multicolumn{2}{|l|}{ Comments } \\
\hline 7.7 & $\begin{array}{l}\text { Where financial agencies oversee consumer protection arrangements (such as dispute } \\
\text { settlement processes), information on such arrangements should be publicly disclosed. }\end{array}$ \\
\hline Description & $\begin{array}{l}\text { Although the BI does not oversee consumer protection, it has established disclosure practices for } \\
\text { the banks' own consumer rights and dispute settlement arrangements. }\end{array}$ \\
\hline Assessment & Not applicable \\
\hline Comments & $\begin{array}{l}\text { Although under provisions of the Banking Law and Consolidated Law the BI is not assigned any } \\
\text { responsibilities in consumer protection arrangements, a regulation issued by the BI (largely } \\
\text { redrafted in 2003) regarding disclosure of banking transactions and services stipulates that banks } \\
\text { disclose to the public all the relevant complaints processes and legal ways designed to protect } \\
\text { consumer rights, both formal (before a civil court) or not. The BI also answers consumer queries } \\
\text { and complaints concerning those dealings and operations. }\end{array}$ \\
\hline
\end{tabular}




\begin{tabular}{|c|c|}
\hline & $\begin{array}{l}\text { The most relevant means of nonjudicial protection of customers in banking and financial sector are } \\
\text { the "ombudsman office," taken in place by an agreement drafted by the Italian banking association } \\
\text { (ABI), and the "settlement commissions," provided by the Legislative Decree n. } 5 \text { of } 17 \\
\text { January } 2003 \text {. The former has competence for the solution of disputes among banks and their } \\
\text { clients, as long as the value of such disputes is not too high, and its decisions are boundaries only } \\
\text { for the banks; the latter have a broader competence in matters regulated by the Banking Law and } \\
\text { the Consolidated law on Financial Intermediation and can pronounce decisions binding all the } \\
\text { parties involved; in both cases, BI does not have any responsibility in this matter. } \\
\text { According to Legislative Decree } 28.7 .2000, n \text {. } 253 \text {, implementing EU Directive } 97 / 5 \text { on cross } \\
\text { border credit transfers, banks and other intermediaries operating cross border credit transfers (in } \\
\text { the meaning of the Directive), must have dispute settlement processes in place. Criteria regulating } \\
\text { the process and the composition of the decision bodies have been determined by the Decree of the } \\
\text { Ministry of Economy and Finance } 13.12 .2001, \text { n. } 456 \text {. Art. } 2 \text { (2) of the Decree requires } \\
\text { intermediaries to provide customers with adequate information about the appointment of the } \\
\text { deciding bodies and the settlement procedures, with the aim of ensuring the easiest access to them } \\
\text { for customers. }\end{array}$ \\
\hline \multicolumn{2}{|r|}{ VIII. ACCOUNTABILITY AND ASSURANCES OF INTEGRITY BY FINANCIAL AGENCIES } \\
\hline 8.1 & $\begin{array}{l}\text { Officials of financial agencies should be available to appear before a designated public } \\
\text { authority to report on the conduct of financial policies, explain the policy objective(s) of their } \\
\text { institution, describe their performance in pursuing their objective(s), and, as appropriate, } \\
\text { exchange views on the state of the financial system. }\end{array}$ \\
\hline Description & $\begin{array}{l}\text { The BI publicly reports on questions within the scope of its authority in parliamentary hearings } \\
\text { (see 7.4.2) and at meetings of the ICCS. The purpose is to report on the conduct of financial } \\
\text { policies, explain policy objectives, and exchange views on the state of the financial system. There } \\
\text { is no pre-specified schedule for these appearances, they occur whenever the Parliament needs } \\
\text { technical advice on subjects related to the functions of the BI. The meetings of the ICCS are not } \\
\text { subject to a pre-specified schedule. Officials of the BI are not required by law to appear before a } \\
\text { designated public authority, but, they stand available to do so. Testimonies before Parliament are } \\
\text { generally by held the Governor, the Director General and the Deputies of the Director General, } \\
\text { and, occasionally, by other senior officials. }\end{array}$ \\
\hline Assessment & Observed \\
\hline \multicolumn{2}{|l|}{ Comments } \\
\hline 8.2 & $\begin{array}{l}\text { Where applicable, financial agencies should publicly disclose audited financial statements of } \\
\text { their operations on a pre-announced schedule. }\end{array}$ \\
\hline Description & $\begin{array}{l}\text { The BI publicly discloses its audited financial statement (balance sheet, income statement, the } \\
\text { notes to the accounts) in the Annual Report, issued no later than five months following the end of } \\
\text { its financial year (see also 7.3). }\end{array}$ \\
\hline Assessment & Observed \\
\hline \multicolumn{2}{|l|}{ Comments } \\
\hline 8.2 .1 & $\begin{array}{l}\text { Financial statements, if any, should be audited by an independent auditor. Information on } \\
\text { accounting policies and any qualification to the statements should be an integral part of the } \\
\text { publicly disclosed financial statements. }\end{array}$ \\
\hline Description & $\begin{array}{l}\text { According to Article } 27 \text { (1) of the ESCB Statute, the accounts of the BI are audited by independent } \\
\text { external auditors recommended by the Governing Council of the ECB and approved by the }\end{array}$ \\
\hline
\end{tabular}




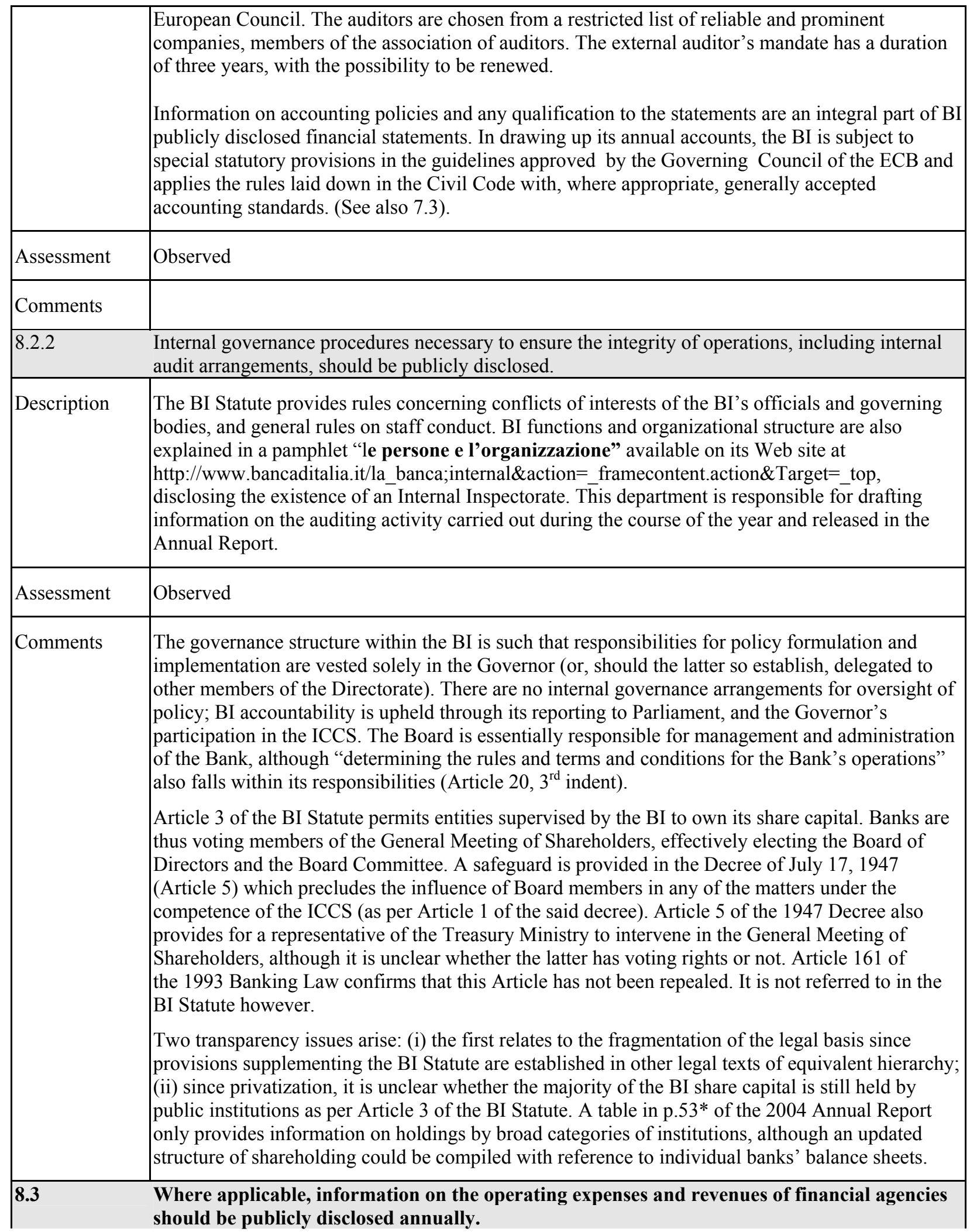




\begin{tabular}{|c|c|}
\hline Description & $\begin{array}{l}\text { The BI financial statements, published in the Annual Report (see 7.3) include information on } \\
\text { operating expenses and revenues. }\end{array}$ \\
\hline Assessment & Observed \\
\hline \multicolumn{2}{|l|}{ Comments } \\
\hline 8.4 & $\begin{array}{l}\text { Standards for the conduct of personal financial affairs of officials and staff of financial } \\
\text { agencies and rules to prevent exploitation of conflicts of interest, including any general } \\
\text { fiduciary obligation, should be publicly disclosed. }\end{array}$ \\
\hline Description & $\begin{array}{l}\text { There are standards for the conduct of personal financial affairs of officials and staff of the } \\
\text { financial agency and rules to prevent exploitation of conflicts of interest but they are not publicly } \\
\text { disclosed. Only the general rules of conduct for staff as provided for in the BI's Statute (see 8.2.2) } \\
\text { are disclosed. } \\
\text { Detailed rules are contained in an internal staff regulation (Regolamento del Personale) which is } \\
\text { deposited with the CNEL (Consiglio nazionale dell'economia e del lavoro). Although the rules are } \\
\text { not publicly disclosed, they are summarized in a text on organization and operations on the BI Web } \\
\text { site, and are available upon request from CNEL. } \\
\text { - Title III, Part I of the internal staff regulation contains rules concerning the obligations, } \\
\text { prohibitions, incompatibilities and responsibility of BI staff. According to Article 12 (4.d), } \\
\text { employees are obliged to notify the BI of any interests-financial or nonfinancial in } \\
\text { nature- that they and their relatives may have with respect to matters falling within the } \\
\text { remit of the office to which they are assigned and which can generate potential conflicts of } \\
\text { interest. } \\
\text { By virtue of this regulation staff are prevented from taking advantage of knowledge on } \\
\text { activities performed by the BI, from performing activities that run counter to the interests } \\
\text { of the BI, taking on other employment, and engaging in securities transactions in stock } \\
\text { exchanges. } \\
\text { The staff regulations also govern procedures relating to the application of disciplinary sanctions. A } \\
\text { special body called "Commissione di disciplina" proposes the disciplinary sanctions to be applied } \\
\text { in the case of irregularities committed by staff. The members of the Commissione di disciplina are } \\
\text { designated by the Governor; they are one Deputy Director General who acts as chairman, the head } \\
\text { of the Personnel Management Department and three other members chosen among senior staff. The } \\
\text { following disciplinary sanctions may be imposed: (i) censure; (ii) reduction in salary; (iii) } \\
\text { suspension (with suspension of salary payment) for a period of } 6 \text { months to 1 year; (iv) dismissal. }\end{array}$ \\
\hline Assessment & Observed \\
\hline \multicolumn{2}{|l|}{ Comments } \\
\hline 8.4 .1 & $\begin{array}{l}\text { Information about legal protections for officials and staff of financial agencies in the conduct of } \\
\text { their official duties should be publicly disclosed. }\end{array}$ \\
\hline Description & $\begin{array}{l}\text { There is no specific provision offering legal protection to the BI and its employees, which in the } \\
\text { performance of their supervisory functions are public officials, against the possibility of legal } \\
\text { action stemming from measures adopted in the performance of their functions. }\end{array}$ \\
\hline Assessment & Not applicable \\
\hline Comments & \\
\hline
\end{tabular}


Recommended action plan and authorities' response to the assessment

Recommended action plan

6. The summary table contains recommended steps for improving observance of the MFPT Code. Only the practices with respect to which specific recommendations are being made are listed. 
Table 2. Recommended Action Plan to Improve Observance of IMF’s MFP Transparency Code Practices-Banking Supervision

\begin{tabular}{|c|c|}
\hline Reference Practice & Recommended Action \\
\hline \multicolumn{2}{|l|}{$\begin{array}{l}\text { V. Clarity of Roles, Responsibilities and } \\
\text { Objectives of Financial Agencies Responsible for } \\
\text { Financial Policies }\end{array}$} \\
\hline $\begin{array}{l}\text { 5.1.1 The broad objective(s) of financial agencies } \\
\text { should be publicly disclosed and explained. }\end{array}$ & $\begin{array}{l}\text { Publicly disclose and explain the objectives of stability, } \\
\text { efficiency and competitiveness. }\end{array}$ \\
\hline $\begin{array}{l}\text { 5.1.4 Where applicable, the procedures for } \\
\text { appointment, terms of office, and any general } \\
\text { criteria for removal of the heads and members of the } \\
\text { governing bodies of financial agencies should be } \\
\text { publicly disclosed. }\end{array}$ & $\begin{array}{l}\text { Publicly disclose the applicability of Article } 14.2 \text { of the ESCB } \\
\text { Statute as regards the dismissal of the Governor and the general } \\
\text { criteria for removal of the heads and members of the governing } \\
\text { bodies in the absence of such provisions in the BI Statute. } \\
\text { Further to this recommendation, BI has amended the on-line } \\
\text { pamphlet entitled "le persone e l'organizzazione." The recently } \\
\text { adopted Savings Law now explicitly mentions Article } 14.2 \text { of } \\
\text { the ESCB Statute for the Governor's dismissal procedures. }\end{array}$ \\
\hline \multicolumn{2}{|c|}{\begin{tabular}{|l|l|} 
VI. Open Process for Formulating and Reporting & \\
Financial Policies
\end{tabular}} \\
\hline $\begin{array}{l}\text { 6.1.5 Where applicable, formal procedures for } \\
\text { information sharing and consultation between } \\
\text { financial agencies (including central banks), } \\
\text { domestic and international should be publicly } \\
\text { disclosed. }\end{array}$ & $\begin{array}{l}\text { Publicly disclose the details on protocols that define the } \\
\text { practical modalities of cooperation between domestic financial } \\
\text { agencies, and the actual procedures that are followed for } \\
\text { information sharing. Further to this recommendation, the MOU } \\
\text { governing the cooperation and exchange of information } \\
\text { between BI and Consob was made public on the Web site of the } \\
\text { two institutions. }\end{array}$ \\
\hline \multicolumn{2}{|l|}{$\begin{array}{l}\text { VII. Public Availability of Information of } \\
\text { Financial Policies }\end{array}$} \\
\hline $\begin{array}{l}\text { VIII. Accountability and Assurances of Integrity } \\
\text { by Financial Agencies }\end{array}$ & \\
\hline
\end{tabular}

\section{Authorities' response ${ }^{3}$}

7. BI notes the assessment's recognition of the very high degree of compliance of the Italian banking supervisory system with the IMF Code of Good Practices on Transparency in Monetary and Financial Policies (MFPT Code). The assessment highlights such positive features as: (i) the extensive information on banking supervision made publicly available through the Annual Report, the publication of all general measures in the Gazzetta Ufficiale della Repubblica Italiana and in the Bollettino di vigilanza, the wide-ranging and detailed

\footnotetext{
${ }^{3}$ If no such response is provided within a reasonable time frame, the assessors will provide a brief summary of the authorities' reactions at the conclusion of the discussions.
} 
statistical publication program, the frequent Parliamentary hearings and speeches by the Governor, other top officers and senior officials; (ii) BI's cooperation with other domestic and foreign financial agencies in day-to-day activities through exchange of information and coordinated action (the Memorandums of Understanding with Consob and ISVAP are available on both authorities' Web sites); (iii) the practice of public consultation with market participants on significant regulatory changes.

8. Practice 5.1.1. BI observes that the Annual Report contains a section (about. 100 pages in length) setting out the criteria, methods and results of supervisory activities, fulfilling the accountability obligation established by the 1993 Banking Law. The objectives of the banking supervisory function were explained initially in the 1993 Annual Report. Since then all relevant supervisory issues have been regularly discussed. For instance, the 2003 Annual Report has a detailed description of criteria and methods of supervision, while the 2004 Report focuses on regulatory changes such as the implementation of Basel II and IAS/IFRS, structural changes in the banking system such as international openness, and methods of macroprudential analysis. That is to say, the objectives for which the Bank is responsible are explained on an ongoing basis and that any significant modification of the Bank's stance is announced in a timely fashion. The Savings Law now provides for halfyearly reporting to both Parliament and Government.

9. $\mathrm{BI}$ is studying the possibility of bringing out a new report on the evolution of the Italian banking and financial system and the issues relevant to its regulatory and supervisory mandate.

10. As regards links between the different objectives set out in Article 5 of the Consolidated Law on Banking (1993) — sound and prudent management of individual banks, the overall stability, efficiency and competitiveness of the financial system, and compliance with the provisions concerning credit-legislators deemed the objectives to be strictly complementary. BI shares this view, in that competition is essential to efficiency (both operating efficiency and in the allocation of resources) and hence to financial stability. More specifically, the stability and the efficiency of the banking system are objectives common to all supervisory authorities; and competitiveness, including that of the system as a whole, has been interpreted as referring to the necessity that the prices and the quality of the products and services offered by Italian banks meet the needs of firms and households.

11. As regards the dismissal of the Governor, BI observes that Article 19.8 of the Savings Law established a new procedures for the appointment and dismissal of the Governor that refers to article 14.2 of the $\mathrm{ESCB} / \mathrm{ECB}$ Statute as being directly enforceable in all Member States; the grounds for its application are found in the principle of equal treatment throughout the ESCB. Without prejudice to remedies provided by national jurisdictions, to ensure uniform judgment in all the Member States on this matter, any decision concerning the dismissal of a Governor may be referred to the Court of Justice by the Governor concerned or by the Governing Council of the ECB on grounds of infringement of the Treaty or of any rule of law relating to its application. BI Statute provides for the appointment and dismissal of the Director General and the two Deputy Directors General. The principles and criteria for 
dismissal are specified in the general administrative law framework on public duties and in case law, according to which officials may be removed for failure to act in accordance with the purposes of their institutions. The EMI and ECB Convergence Reports and the ECB opinion imply that the safeguards against arbitrary dismissal in the ESCB/ECB Statute also apply to the Director General and the two Deputy Directors General who perform ESCBrelated tasks. This applies in particular where they serve as deputy for the Governor.

12. As regards responsibilities for policy formulation and implementation, the Savings Law has attributed them to the whole Directorate. 